\title{
The Role of Economics, Politics and Institutions on Budget Deficit in ASEAN Countries
}

\author{
Minh Ngoc NGO ${ }^{1}$, Loc Duc NGUYEN ${ }^{2}$
}

Received: July 03, 2020 Revised: July 25, 2020 Accepted: August 10, 2020

\begin{abstract}
The paper examines the role of some determinants of economics, politics and institutions on the budget deficit volatility in some countries of the Association of South East Asian Nations (ASEAN) such as Indonesia, Thailand and Vietnam. The paper uses the fixed effects model (FEM) and the random effects model (REM) to investigate panel data of these countries in the period of 1990-2018. Moreover, the study also explores ordinary least square (OLS) to analyze time-series data for each country in the same period to make comparison among them. The economic data is collected from international financial statistics and world development indicators. The data on political variables are collected from International Country Risk Data Guide (ICRG). The empirical results both confirm that corruption and political stability are important indicators of budget deficit. Besides, the paper suggests authorities should pay more attention on improving the institutional setup of the economy in order to avoid high and unstable deficit. The findings offer new insight on the budget deficit in essence and suggest that the most important thing need to be done ahead is to strongly implement anti-corruption actions. By doing so, the status of budget deficit would be remarkably improved immediately.
\end{abstract}

Keywords: Macroeconomic Stability, Institution, Budget Deficit, ASEAN

JEL Classification Code: E60, H62, H68

\section{Introduction}

In recent years, the degree of government budget deficits and debt became the most prominent issues in economics on which a lot of discussions are conducted. Instable fiscal deficits may be damaging to social welfare because past literature has definitely shown that fiscal debt is negatively associated with the long-run fiscal balance of the economy, so future generation may suffer very easily (Alesina and Perotti, 1996; Alesina and Rodrik, 1994). Central bank is deficient in independence and, as inflation and budget

${ }^{1}$ First Author and Corresponding Author. Faculty of Business Administration, Industrial University of Hochiminh City, Vietnam [Postal Address: 12 Nguyen Van Bao Street, Ward 6, Go Vap District, Hochiminh City, 727900, Vietnam] Email: ngongocminh@iuh.edu.vn ${ }^{2}$ Faculty of Business Administration, Industrial University of Hochiminh City, Vietnam. Email: nguyenducloc@iuh.edu.vn

(C) Copyright: The Author(s)

This is an Open Access article distributed under the terms of the Creative Commons Attribution Non-Commercial License (https://creativecommons.org/licenses/by-nc/4.0/) which permits unrestricted non-commercial use, distribution, and reproduction in any medium, provided the original work is properly cited. deficit are closely related, so persistent budget deficit may also raise inflation. A lot of efforts are required to recognize the determinants of the large public deficits although many researchers have tried, but still needs more contribution in this context.

In the past, budget deficits were considered only as an economic issue, but the beginning of political economics in 1980s triggered researchers to observe this subject both from the economic and political perspectives. After the first oil crisis in 1973 many industrialized countries had been facing the problem of significant high budget deficits, and it is interesting to note that, even in the prosperous years, countries were facing problem of budget deficit when there was high growth of income, whereas according to the economic theory the deficits should be low during the time when there is high economic growth.

As a result, in the times of high economic growth, the magnitude of debt has been accumulated progressively, and even in countries facing similar economic shocks, the amount of deficits and debt varies in the number of country (Thalassinos et al., 2015a; 2015b; Ugurlu et al., 2014). The current economic philosophy alone may not be considered 
enough and satisfactory to explain the differences in deficits and debt levels across different countries, Therefore, political variables, such as the political stability, corruption, law and order, and conflicts may be included as variables in models in order to give possible explanations for the varying levels of deficits (Woo, 2003; Ngo and Nguyen, 2020).

The developed and developing countries have a key challenge of persistently increasing budget deficits and volatility for numerous reasons. First, huge deficit instability is a failure of fiscal policy because it becomes impossible to suggest at what time and with what degree the fiscal policy is implemented, and this leads to become inefficient decision-making. Second, government spending volatility may be a consequence of the budget deficit instability and the distortions in the form of wasteful spending made by short-term methods to encounter these variations in expenditure. The excellence and competence of the government services, for example health or education, may also be low if government spending volatility depends on fiscal deficit volatility. Third, high budget deficit volatility may also be a reason for capital loss in the form of short-term investment projects. High deficit volatility may also be a reason for high volatility of interest rates, which may directly affect investment projects because it signifies a monetary load for investments. Chen et al. (2017) have shown that there must be an optimal level of public investment and government debt. According to this study, after a maximum level, caught there will be no effect of government debt and investment effect on economic growth. Over the last three decades, models which explain public deficits and hazards and solution to solve the hazards have sustained attention; however, models which explain public deficit instability is somewhat a novel subject to be discussed.

The key emphasis of the current study is to empirically examine the foundations of deficit volatility for some countries using panel data from 1990 to 2018 . The present study is focusing on the economic, political, and institutional factors that cause instability in budget deficits. The current study also draws attention of the economists on the effects of trade openness and inflation on budget deficit instability. The analysis includes the impact of political instability on the budget deficit instability. The current study is focusing on the political variables like corruption, political instability, and military in politics and conflicts. Some ASEAN countries as Indonesia, Thailand and Vietnam are selected because of the common features of their huge unstable public deficit.

To this end, the paper is structured as follows: Section 2 reviews the literature on the determinants affecting budget deficit volatility. Section 3 introduces variables, model and methodology. Section 4 shows the results of empirical research. And Section 5 presents conclusion.

\section{Literature Review}

Over the last thirty years, most developed and developing countries are facing persistence rise of fiscal deficits. Many countries are facing a major challenge in the form of damages due to high fiscal deficit and its volatility (Pontoh, 2017). The subject of budget deficit and its determinants is widely theoretically and empirically studied (Allegret et al., 2016; Boldeanu and Tache, 2016; Yu, 2017). Nevertheless, a lot of efforts are still required in the area of instability of budget deficit. The current section reviews significant studies on this subject.

The topic of budget instability is very broad because of various political variables. In the recent years, the description of particular political explanatory variables, e.g., political stability, size of government, fragmentation of government, type of budgetary procedures, negotiating power of unions, etc., has received substantial consideration (Roubini and Sachs, 1989a, 1989b; De Haan and Sturm, 1994). The budget deficit and surpluses may help to minimize spending and revenue shock if the tax rate is constant over time (Barro, 1979). However, these models are unable to explain the reason for the rise in oil prices following the oil crises in the 1970s. These models are also unsuccessful to provide the answer to why varying levels of fiscal deficits are faced by countries experiencing similar economic shocks. Alesina and Perotti (1995) say it is not possible to understand the issue of budget deficit instability without including the perspective of political and institutional variables because economic theory alone is unsuccessful to resolve this issue (Duguleana and Duguleana, 2016).

The association of political variables and fiscal responses is examined by Person (2001) and Person and Tabellin (2001). The evidence is also found of low anti-cyclical fiscal policy in electoral years in Hallerberg and Strauch (2002) and Sorensen et al. (2001). Few studies show that the government with pro-cyclical polices has instable output (Lane, 2003). Strict budgetary constraint has lower fiscal policy volatility (Fatas and Mihov, 2003; 2006). In developing countries, procyclical fiscal policy may explain higher corruption level (Alesina and Tabellini, 2008).

Discretionary fiscal policy is negatively associated with government size and income (Afonso et al.,2008). According to previous works, the debt is the consequence of a fight between different groups of a population who try to take undue possession of wealth and capital. The debt is a consequence of a group who take advantage of their temporary powers in government. Debt may be used as a tool to redistribute incomes to future generations (Cukierman and Meltzer, 1989; Song et al., 2012). Few studies discuss the accumulation of debt that bound future governments to choose their own policies(Tran and Nguyen, 2020; Persson and Svensson, 1989; Alesina and Tabellini, 1990; Tabellini 
and Alesina, 1990). Studies by Tabellini and Alesina (1990) claim that turnover rate stimulates excess deficits, and Glazer (1989) claims that expected turnover motivates excess investment as incumbents attempt to constrain their successors.

Governments determine both debt and future entitlements. Alesina and Drazen (1989) highlight that political fragmentation is a reason of high cost and delayed fiscal implementation of rules. Tabellini and Alesina (1990) show that parties commit excessive spending if they risk losing elections. Lizzeri (1999) also describes that competition among political parties results in fiscal deficit. Azzimonti et al. (2016) have offered a recent analysis of legal methods to handle unnecessary deficits constructed on the dynamic judicial bargaining model. The authors claim that short-run costs and long-run benefits are associated with balanced budget rule, and it may offset costs of fiscal deficit. According to economists, remarkably high fiscal deficits are permissible only if they are supported by a parliamentary supermajority. The same argument is also made by Becker et al. (2010). Gruner (2017) also paid attention to public expenditure decisions by fiscal policymakers and political parties bargaining for budget.

Persson and Tabellini (1999) found that more redistribution and larger governments are associated with majoritarian elections whereas presidential governments are less redistributive and small. In presidential systems, decisions are more clear and self-governing (Shugart and Carey, 1992). So, economic policy can be implemented without any rescheduling or interference. On the contrary, the parliamentary system depends on the electoral laws. Alesina and Perotti (1995) and Persson and Tabellini (1997) discover that very few occurrences of large fiscal deficit are found in majoritarian and presidential electoral systems compared to proportional-system governments. More occurrences of fiscal deficit are found in countries where there is frequent government turnovers, and in countries where the budget process is lenient. Henisz (2004) suggests that formal checks and balance may recover economic outcomes. Woo (2003) highlights political factors, social polarization and institutional factors. Leachman et al. (2007) demonstrate that, if budget-imposing institutions are strong, fiscal performance may be better. The existing literature found limited empirical evidence of a relationship between income inequality and fiscal deficit. First econometric evidence is provided by Woo (1999) that income inequality is an important factor of fiscal deficits. Alesina and Perotti (1996a) provide evidence that political instability has a positive relation with income inequality. Alesina and Rodrik (1994) and Persson and Tabellini (1994) propose that unequal income distribution in democratic country may incline to favor large redistributive spending. Woo (1999) designed a model to show that large deficits are a consequence of a greater incentive by policymakers to maintain higher spending in the sectors of their choice.

Roubini and Sachs (1989a, 1989b) stress the positive relationship between fiscal deficit and the fragmentation. Edin and Ohlsson (1991) reveal that this conclusion provided by Roubini and Sachs (1989a and 1989b) may be a consequence of classification and measurement of the variable because it captures government fragmentation. Edin and Ohlsson (1991) claim that only minority governments have more inclination to grow huge deficits. De Haan and Sturm (1994) conclude that there is no significant difference among different types governments. Edin and Ohlsson(1991) and Kontopoulos and Perotti (1999) claim that minority governments are associated with greater deficits. More fiscal deficit in minority governments may be because of coordination failure as more members take part in the decision-making process. Nordhaus (1975), Rogoff and Sibert (1988), Rogoff (1990), among others, provide evidence that prior to elections all politicians follow expansionary fiscal policy. Alt and Lassen (2006) discuss that if the political system is transparent politicians cannot take undue benefit and cheat the general public.

Franzese (2002) discussed that political representatives only go for policies that make them win the following elections. Governmental cycles in election years, which rely on these policies, normally display greater fiscal deficits. Mink and De Haan (2005) discover that deficits are inclined to be higher during election years, whereas in the previous year they are not. On the other hand, Andrikopoulos et al. (2004) show that during elections right-wing governments focus on fiscal stabilization. Alesina et al. (1997) found no evidence of higher deficit by left-wing governments. The collected works on the current issue suggests that more research is required to find out the sources of instability of budget deficit to better resolve the issue, with a focus not only on economic variables, but also on the reality from a political perspective.

\section{Methodology}

The current study applies panel data models of equation (1) presented below. The data covers 30 years of observation, from 1990 to 2018, of some ASEAN countries; the panel is unbalanced for estimation of budget deficit volatility. The current study is based on the theoretical work of Alesina and Perotti (1995) and Person and Tabellini (1997) and empirical work of Woo (2003) and Henisz (2004). These studies focus on those institutions that are important for proficient economic activity.

The current study is focusing, not only on the economic variables for deficit instability, but also on the political determinants of budget deficit volatility. For some ASEAN countries, the study is using dynamic panel data models for 
the period from 1990 to 2018 . The empirical specification in dynamic panel data models to identify the features defining the instability of budget deficit is specified below:

$$
\begin{aligned}
B D V_{i, t}= & \alpha B D V_{i, t-1}+\beta E C O N_{i, t}+\gamma I N S T_{i, t} \\
& +\delta C_{i, t}+\vartheta_{i}+\varepsilon_{i, t}
\end{aligned}
$$

In the above equation, volatility of budget deficit for the country $i$ for the period $t$ is denoted by BDV, economic variables are denoted by $\mathrm{ECON}_{\mathrm{it}}$, political and institutional variables are denoted by $\mathrm{INST}_{\mathrm{it}}$, and control variables, which record country special features, $\mathrm{C}_{\mathrm{it}}$.

The economic variables include budget deficit, which is used as a percentage of GDP, trade openness, per-capita real GDP and inflation. The reason for the selection of real GDP per-capita is to record the varying level of economic development among the countries. There are few studies that support a negative relationship between budget deficit and real GDP per capita, and the reason for this negative relationship may be the instable business cycles and inefficient economic institutions (Fatas and Mihov, 2006), and reliance on discretionary fiscal policy.

Nevertheless, the evidence of positive relationship between per capita GDP and budget deficit is also found in few studies. These studies posit that high economic growth produces more resources and wealth and provides as well better solutions for socio-economic issues (Woo, 2003). The reason for inclusion of inflation is to capture its effect because the higher nominal interest and the level of economic uncertainty is the consequence of inflation. Economic uncertainty and volatility of budget deficit are closely related because this may lead to instability in government spending and income, and this instability affects the volatility of budget deficit. Therefore, a positive connection between budget deficit instability and higher inflation is anticipated. The impact of external shocks is recorded by the degree of openness.

In developing countries, external shocks may be a reason for fiscal instability. The trade openness is calculated as exports plus imports ratio to GDP. It is anticipated that trade openness has a positive association with budget deficit instability of the country. For example, Wang et al. (2011) show that trade openness is one more significant determinant of the entire value of houses sold, and this study has captured the effect by using net exports and foreign direct investment. It is expected that, as the level of openness increases, the demand for real estate will increase as well, and will further increase housing. The population growth controls for the size of the country effects and is anticipated to have a negative association to budget deficit volatility. If a country has a large population it means an availability of a large group who pay taxes to government to easily finance its expenditures. This may be due to the benefits of increasing return to scales, consequently the government can provide more goods and services to the public and this leads to less budget deficit instability. The explanatory variables that measure the effect of political instability include political stability, military in politics, corruption and external conflicts.

The early literature describes the instability of budget deficit. The three separate panel data econometric methods are used in this study to fill the research gap. The current study is carried out for some ASEAN countries for the period from 1990 to 2018 using the Fixed Effects and Random Effects Models. Finally, to choose between the fixed effects and random effects approach, the Hausman test is applied. The general econometric representation of the equation for the inclusion of theoretical variables is as follows:

$$
B D V_{\mathrm{i}, \mathrm{t}}=\beta_{0}+\beta_{1} E C O N_{i, t}+\beta_{2} I N S T_{i, t}+\beta_{3} C_{i, t}+\varepsilon_{i, t}
$$

In the above equation volatility of budget deficit is shown by BDV. In this equation i represent country and time period is denoted by $t$, as this is a panel data study. The economic variables are denoted by $\mathrm{ECON}_{\mathrm{it}}$. The political and institutional variables are denoted by INST ${ }_{i t}$ and control variables that record country special features are denoted by $\mathrm{C}_{\text {it }}$

The estimators of fixed effects are also identified as the estimator of least-squares dummy variables (LSDV). In this model each group comprises a separate dummy variable to have different constants for each group. A fixed effects model may be designed as follows to combine effects, which are particular to a country:

$$
B D V_{i, t}=\alpha_{i, t}+\beta_{1} E C O N_{i, t}+\beta_{2} I N S T_{i, t}+\beta_{3} C_{i, t}+\mu_{i, t}
$$

In the above equation, a country effect depending on time. There is another method to estimate the model, namely, random effects model. The random effects method holds the constants for each unit, not as fixed, but random parameter and this is the major differentiation between the two models.

\subsection{Hausman Test for Model Specification}

The current study has used Hausman test to conclude which model is best fit for the current study, whether fixed effects or random effect. If estimators are correlated with individual effect, in this situation the advantage of the use of fixed effects estimator is consistent. The following statistical test used is the Hausman test:

$$
H=\left(\beta^{F E}-\beta^{R E}\right)\left[\operatorname{Var}\left(\beta^{F E}\right)-\operatorname{Var}\left(\beta^{R E}\right)\right]^{1}
$$

If the value of the Hausman test is small and the difference between the estimates is insignificant we may reject the null hypothesis that random effect model is consistent and we 
will use the fixed effects model. On the contrary, a large value of the Hausman test suggests that the random effects models are more suitable.

\subsection{Unit Root Test and Ordinary Least Square Estimates}

To make sure the determinants of budget deficit and to make a comparison between results of panel data and timeseries analysis, this study also look at the source of budget deficit for individual country using time-series data. So, to investigate the stationarity of the basic model is the first step examining the usage of unit root test for three countries, namely, Indonesia, Thailand, and Vietnam. The availability of data set determined the selection of countries for the period 1990 to 2018. We reject the null hypothesis of a unit root test if the critical value is greater than the ADF statistical test and we conclude that the series is stationary.

For a determination of unit root test the data must be first differenced, second differenced and so on until the stationarity is achieved. The Dickey Fuller approach can be considered as an appropriate and simple technique to test the order of integration of the model. However, it has one drawback that it does not take into account the possibility of autocorrelation in the error process $\varepsilon_{t}$, so Dicky Fuller test may not be considered suitable. To reduce this problem, the Augmented Dickey-Fuller (ADF) test simply solves this problem. The three countries under examination are applied the OLS estimates using time-series data depending upon the availability of data set from 1990 to 2018 .

\subsection{Data and Sample}

The current study has collected data, not only for economic variables, but also for the political variables using panel data from 1990 to 2018. Economic variables are obtained through international financial statistics (IFS) and world development Indicators (WDI). The source of political variables is International Country Risk Data Guide (ICRG).

The current study is using several economic variables like ratio of budget deficit to GDP, real GDP per capita, trade openness and inflation. The reason for the inclusion of inflation variable is to confirm the expected positive relationship between budget deficit and inflation. The ratio of trade to GDP represents trade openness and it captures the external shocks. The population growth is used as a control variable to capture the effect of country size of each country.

The political variables such as government/political stability, external conflict, corruption, and military in politics are included to find out the impact of governmental uncertainty on budget deficit volatility. This study is using a political index provided by the International Country Risk
Data Guide. Each political risk point is shown by a number assigned by this index. The maximum number of points is assigned after assessment of overall risk, and the minimum number of point is zero. In this index, a lower total risk is shown by a high-risk point and a higher total risk is shown by lower-risk point.

\section{Empirical Results and Discussion}

This study explores the determinants of budget deficit volatility by application of panel data models. For the present analysis fixed and random effects models are applied and, then, the Hausman test to select which model is best fit from the two approaches. The current study is designed to confirm the determinants of budget deficit for some ASEAN countries for the period from 1990 to 2018 .

The estimates of fixed and random effects are shown in Table 1 . The equation of fixed effects model explains that all variables are expected to be significant, but the effect of military in politics and external conflicts are not significant for some ASEAN countries. According to Table 1, budget deficit is positively and significantly associated with inflation and real GDP per capita. Wu et al. (2015) have shown that budget deficit has a positive effect on land prices. The countries with the higher level of income have more variation in budget deficit; this may be the reason for the positive association between the two variables. This may be due to the developmental projects of the country as it needs more funds to finance them, and few studies have also shown the same relationship (Fatas \& Mihov, 2006, 2010; Woo, 2003). The result shows that the budget volatility and population growth have a negative relationship. This may be due to the welfares effect of increasing return to scales. It is possible for the government to make available more welfare projects without affecting budget deficit if there is a large pool of taxpayers as the population grows.

The results of the fixed effects model show that trade openness has insignificant positive association with budget deficit. In developing countries, external shocks may be a reason for fiscal instability. Variations in export and import prices can affect budget deficit through exports profits or import tariffs. Positive association of trade openness with budget deficit is also shown by Agnello and Sausa (2009). It has been shown that the effectiveness of fiscal policy depends on the efficient political setup (Alesina and Perotti, 1995 ) and this is proved by empirical evidence provided by different studies (Woo, 2003; Alesina and Parotti, 1996; Fatas and Mihov, 2003). In this analysis, which records the impact of political and institutional variables, political stability and corruption are included and these are significant, and with budget deficit these are positively associated as shown in Table 1. Military in politics and conflicts had been also expected to be significant, but their effect is not significant. 
Table 1: Fixed effects and random effects of some ASEAN countries

\begin{tabular}{|l|c|c|}
\hline Dependent variable : Budget deficit ${ }_{\mathrm{i}, \mathrm{t}}$ & \multicolumn{2}{|c|}{ Random effects } \\
\hline Independent variables & Fixed effects & $0.105746^{*}$ \\
C & $0.129234^{*}$ & $(5.76)$ \\
\hline \multirow{2}{*}{ GDP per capita } & $(3.64)$ & $3.81 \mathrm{E}-10$ \\
& $3.14 \mathrm{E}-09^{*}$ & $(1.17)$ \\
\hline Population & $(6.37)$ & $-0.024086^{*}$ \\
& $-0.056845^{*}$ & $(-6.04)$ \\
\hline Trade openness & $(-5.80)$ & $-0.036895^{*}$ \\
& 0.008587 & $(-6.81)$ \\
\hline Inflation & $(0.55)$ & $-0.000125^{* *}$ \\
& $0.000666^{*}$ & $(-1.90)$ \\
\hline \multirow{2}{*}{ Corruption } & $(3.19)$ & 0.006956 \\
& $-0.001603^{*}$ & $(2.24)$ \\
\hline Political stability & $(-2.82)$ & $-0.003195^{*}$ \\
& $-0.005839^{*}$ & $(-2.66)$ \\
\hline \multirow{2}{*}{ Military in Politics } & $(-2.59)$ & $0.006539^{*}$ \\
& -0.001603 & $(3.52)$ \\
\hline \multirow{2}{*}{ External conflicts } & $(-0.48)$ & $-0.002452^{* * *}$ \\
& -0.000365 & $(-1.74)$ \\
\hline R-Squared & $(-0.17)$ & 0.182510 \\
\hline Adjusted R-Squared & 0.799963 & 0.153951 \\
\hline
\end{tabular}

Note: The * indicates significant at $1 \%,{ }^{* *}$ indicates significant at $5 \%$ and ${ }^{* * *}$ indicates significant at $10 \%$.

The results of random effect model illustrated that budget deficit is not significant for inflation, corruption and military in politics for a given set of countries. The Hausman test is presented in Table 2 to compare the results of fixed effects with the random effect. The fixed effects model is the best fit model for the current study as shown by the $\mathrm{P}$ value $=0.00$. Hausman statistical test is very small so we can conclude the difference between the estimates is insignificant and use fixed effects model and reject the null hypothesis, which represents consistency of random effect model.

To identify the determinants of budget deficit and to make a comparison between results of panel data and timeseries analysis, this study also looks at the source of budget deficit for individual country using time-series data. First, the current study is using unit root to test stationarity of the model for Indonesia, Thailand, and Vietnam. For the timeseries analysis the selection of countries depends on the availability of data from 1990 to 2018 . We conclude that the series is stationary and we reject the null hypothesis of a unit root test if the ADF critical value is more than the ADF statistical test.

The second step is to apply Ordinary Least Square estimates on the data set of countries under consideration. This may help to roughly compare the panel data and
Table 2: Hausman test for model specification (Random vs. Fixed Effects)

\begin{tabular}{|l|c|}
\hline Statistic & P_value $_{-}$ \\
\hline$X^{2}=441.85$ & 0.000 \\
\hline
\end{tabular}

Note: $P$-value and $X^{2}$ are the probability value and Chi-square, respectively.

time-series estimates to determine the sources of budget deficit. Table 3 presents the unit root test for Indonesia. It indicates that all variables are found stationary at first difference except population. Population is stationary at second difference. Table 4 presents the unit root test for Thailand. It indicates that all variables are found stationary at first difference except population. Population is stationary at the initial level.

For Vietnam, the unit root test is presented in Table 5. It indicates that all variables are found stationary at first difference except inflation. Inflation is stationary at second difference. Since all variables are stationary and there is no problem of autocorrelation, then, the second step is to apply OLS to find out the determinants of budget deficit on the equation of selective countries depending on the availability of data set from 1990 to 2018 . 
Table 3: Unit root test: Indonesia

\begin{tabular}{|c|c|c|c|}
\hline Variables & Level & First difference & Second difference \\
\hline Budget Deficit & -2.10 & $-6.47^{* *}$ & \\
\hline GDP per capita & 0.17 & $-3.77^{* *}$ & \\
\hline Trade openness & $-3.36^{* * *}$ & $-8.14^{\star *}$ & \\
\hline Inflation & -1.70 & $-4.70^{\star *}$ & \\
\hline Population & -2.08 & -2.37 & $-3.50^{* * *}$ \\
\hline Corruption & 1.79 & $-3.87^{* *}$ & \\
\hline Political stability & -2.53 & $-6.72^{* *}$ & \\
\hline Military in Politics & -0.67 & $-5.7-* *$ & \\
\hline External Conflicts & $-3.24^{* * *}$ & $-3.97^{* *}$ & \\
\hline
\end{tabular}

Note: ${ }^{*},{ }^{* *}$ and ${ }^{* * *}$ denotes significance at $1 \%, 5 \%$ and $10 \%$, respectively.

Table 4: Unit root test: Thailand

\begin{tabular}{|c|c|c|c|}
\hline Variables & Level & First difference & Second difference \\
\hline Budget Deficit & -2.57 & $-5.83^{* *}$ & \\
\hline GDP per capita & 1.21 & $-4.74^{\star *}$ & \\
\hline Trade openness & -1.64 & $-5.96^{* *}$ & \\
\hline Inflation & -2.79 & $-5.05^{* *}$ & \\
\hline Population & $-4.09^{* *}$ & & \\
\hline Corruption & -1.44 & $-6.19^{* *}$ & \\
\hline Political stability & -1.84 & $-5.72^{* *}$ & \\
\hline Military in Politics & -0.62 & $-4.31^{* *}$ & \\
\hline External Conflicts & -0.82 & $-3.61^{* *}$ & \\
\hline
\end{tabular}

Note: ${ }^{*},{ }^{* *}$ and ${ }^{* * *}$ denotes significance at $1 \%, 5 \%$ and $10 \%$, respectively.

Table 5: Unit root test: Vietnam

\begin{tabular}{|c|c|c|c|}
\hline Variables & Level & First difference & Second difference \\
\hline Budget Deficit & -2.00 & $-5.79^{\star *}$ & \\
\hline GDP per capita & 1.50 & $-5.17^{\star *}$ & \\
\hline Trade openness & -2.98 & $-7.49^{* *}$ & \\
\hline Inflation & 3.05 & -2.33 & $-4.37^{\star *}$ \\
\hline Population & 1.53 & $-5.52^{* *}$ & \\
\hline Corruption & -2.51 & $-5.64^{\star *}$ & \\
\hline Political stability & -1.48 & $-5.10^{* *}$ & \\
\hline Military in Politics & -1.87 & $-4.42^{\star *}$ & \\
\hline External Conflicts & -2.93 & $-4.90^{* *}$ & \\
\hline
\end{tabular}

Note: ${ }^{*},{ }^{* *}$ and ${ }^{* * *}$ denotes significance at $1 \%, 5 \%$ and $10 \%$, respectively. 
Table 6: Ordinary Least Square estimates

\begin{tabular}{|l|c|c|c|}
\hline Dependent variable & \multicolumn{3}{|c|}{ Budget deficit ${ }_{\text {it }}$} \\
\hline Country & Indonesia & Thailand & Vietnam \\
\hline Independent variables & \multicolumn{3}{|c|}{0.30} \\
\hline C & $-0.19^{* *}$ & -0.09 & $(1.26)$ \\
\hline \multirow{2}{*}{ GDP per capita } & $(-2.23)$ & $(-1.07)$ & -0.000004 \\
& $0.000000003^{* *}$ & $-0.000002^{* *}$ & $(-1.49)$ \\
\hline \multirow{2}{*}{ Population } & $-(3.87)$ & $(-3.32)$ & $-0.15^{* *}$ \\
& $0.036^{* *}$ & 0.01 & $(-3.61)$ \\
\hline \multirow{2}{*}{ Trade openness } & $(6.07)$ & $(0.52)$ & 0.10 \\
& 0.013 & $-0.26^{* *}$ & $(0.25)$ \\
\hline \multirow{2}{*}{ Inflation } & $(0.49)$ & $(-5.25)$ & $0.004^{* * *}$ \\
& $0.002^{* * *}$ & $0.008^{* *}$ & $(1.37)$ \\
\hline \multirow{2}{*}{ Corruption } & $(6.07)$ & $(4.74)$ & $0.03^{* * *}$ \\
& $-0.001^{* *}$ & -0.02 & $(1.63)$ \\
\hline \multirow{2}{*}{ Political stability } & $-(4.21)$ & $(-1.36)$ & $-0.0^{* *}$ \\
& 0.0019 & 0.003 & $(-2.30)$ \\
\hline Military in Politics & $(0.92)$ & $(0.74)$ & -0.01 \\
& $0,010^{* * *}$ & 0.007 & $(-0.46)$ \\
\hline \multirow{2}{*}{ External conflicts } & $(1.76)$ & $(0.65)$ & 0.005 \\
& 0.003 & $-0.01^{* *}$ & $(0.75)$ \\
\hline R-Squared & $(0.90)$ & $(-2.61)$ & 0.83 \\
\hline Adjusted R-Squared & 0.94 & 0.80 & 0.77 \\
\hline
\end{tabular}

Note: The asterisks ${ }^{*},{ }^{* *},{ }^{* * *}$ indicate significance at 1,5 and 10 percent, respectively

The least square estimates for the equation of budget deficit are applied to four countries being studied, including India. Table 6 presents the outcome of OLS estimates. The outcome shows that, in the case of Indonesia, only real GDP per capita has a significant and positive association with budget deficit. It is also positive in the case of India, but not significant. In the case of Thailand and Vietnam, real GDP per capita is negatively associated, but it is significant only for Thailand. Inflation has a robust effect on budget deficit in the case of all three countries. The outcome shows positive association of population with budget deficit in the case of Indonesia, but it has non-significant effect for Thailand only. For Vietnam, population growth has negative and significant relationship with budget deficit. Trade openness is a source of fiscal instability especially in Indonesia, for Vietnam it is not significant. It has negative and significant effect in the case of Thailand only. The current analysis includes the recording of the effect of political variables, political stability and corruption. Corruption is positively associated with budget deficit, but it is significant only for Indonesia, as shown in Table 6. Political stability is negatively and significantly associated only for Vietnam. The outcome of the current study indicates that budget is more stable the higher the political stability. An external conflict has the expected significance only for Thailand and it is significant as shown in Table 6.

\section{Conclusion}

The current study has a major objective to examine, not only the economic determinants of budget deficit, but also to focus on political variables as well for some ASEAN countries from 1990 to 2018. The determinants of budget deficit instability are estimated by application of panel data and time-series models. For the application of panel data, fixed effects and random effect models are used. Hausman statistical test is used to select the best fit model for the current study. The fixed effects model is the best fit model according to the result of Hausman test.

The outcome of the fixed effects model explains that all variables are significant, but the effect of military in politics and external conflicts are not significant for some ASEAN 
countries. The results of the fixed effects model show that inflation and real GDP per capita exercise a robust effect on budget deficit. The results show that the budget deficit volatility and population growth have a negative association. This result may be due to the benefits of increasing return to scale as it is possible for the government to provide more welfare projects as there is a large group of tax payers as the population increases. In the present analysis trade openness has shown a positive relationship with budget deficit. This may be due to the rise in the import prices in the sample countries.

The current study matches the results of panel data and time-series analysis, and concludes that corruption and political stability are important indicators of budget deficit. Institutional variables are also very important determinants of budget deficit. The outcome indicates that the budget is more stable with the higher level of political stability. The budget deficit experiences more fluctuations if higher level of corruption coexists. Military in politics and conflicts had been expected to be significant, but their effect is not significant.

\section{References}

Afsono, A., Agnello, A., \& Furceri, D. (2008). Fiscal policy responsiveness, persistence, and discretion. OECD Economics Department Working Papers No.659. Paris, France: OECD. https://doi.org/10.1787/228864226783

Agnello, L., \& Sousa, R. M. (2009). The Determinants of Public Deficit Volatility. ECB Working Paper No. 1042. Frankfurt, Germany: European Central Bank Available at: https://www. ecb.europa.eu/pub/pdf/scpwps/ecbwp1042.pdf

Alt, J. E., \& Lassen, D. D. (2006). Fiscal transparency, political parties, and debt in OECD countries. European Economic Review, 50(6), 1403-1439. https://doi.org/10.1016/j.euroecorev.2005.04.001

Alesina, A., \& Rodrik, D. (1994). Distributive politics and economic growth. The Quarterly Journal of Economics, 109(2), 465-490. https://doi.org/10.2307/2118470

Alesina, A., \& Abellini, G. (1990). A positive theory of fiscal deficits and government debt. The Review of Economic Studies, 57(3), 403-414. DOI: 10.2307/2298021

Alesina, A., \& Drazen, A. (1989). Why are Stabilizations Delayed? The American Economic Review, 81(5), 1170-1188. https:// www.jstor.org/stable/2006912

Alesina, A., \& Perotti, R. R. (1995). The political economy of budget deficits. IMF Staff Papers, 42, 1-31.

Alesina, A., \& Perotti, R. R. (1996a). Income distribution, political instability, and investment. European Economic Review, 40(6), 1203-1228. https://doi.org/10.1016/00142921(95)00030-5

Alesina, A., \& Perotti, R. R. (1996). Budget Institutions and Budget Deficits. NBER Working Paper No. 5556. Cambridge, MA:
National Bureau of Economic Research. https://www.nber.org/ papers/w5556

Alesina, A., Campante, F. R., \& Tabellini, G. (2008). Why is fiscal policy often procyclical? Journal of the European Economic Association, 6(5), 1006-1036. https://www.jstor.org/ stable/40283091

Alesina, A., Roubini, N., \& Cohen, G. D. (1997). Political cycles and the macroeconomy. Cambridge, MA: MIT Press.

Allegret, J. P., Raymond, H., \& Rharrabti, H. (2016). The Impact of the Eurozone Crisis on European Banks Stocks, Contagion or Interdependence. European Research Studies Journal, 19(1), 129-148.

Azzimonti, M., Battaglini, M., \& Coate, S. (2016). The costs and benefits of balanced budget rules: Lessons from a political economy model of fiscal policy. Journal of Public Economics, 136, 45-61. https://doi.org/10.1016/j.jpubeco.2016.03.001

Andrikopoulos, A., Loizides, I., \& Prodromidis, K. (2004). Fiscal policy and political business cycles in the EU. European Journal of Political Economy, 20(1), 125-152. https://doi. org/10.1016/j.ejpoleco.2003.02.001

Barro, R. J. (1979). On the determination of the public debt. Journal of Political Economy, 87(5 Part 1), 940-971.

Boldeanu, T. F., \& Tache, I. (2016). The Financial System of the EU and the Capital Markets Union. European Research Studies Journal, 2016(1), 59-70.

Becker, J. G., Gersbach, H., \& Grimm, O. R. (2010). Debt-sensitive majority rules. CEPR Discussion Paper No. 7860. London, UK: Centre for Economic Policy Research. Available at: http://www.cepr.org/active/publications/discussion_papers/ dp.php?dpno $=7860$

Chen, C., Yao, S., Hu, P., \& Lin, Y. (2017). Optimal government investment and public debt in an economic growth model. China Economic Review, 45, 257-278. https://doi.org/10.1016/j. chieco.2016.08.005

Cukierman, A., \& Meltzer, A. H. (1989). A political theory of government debt and deficits in a neo-Ricardian framework. American Economic Review, 79(4), 713-732.

De Haan, J., \& Sturm, J. E. (1994). Political and institutional determinants of fiscal policy in the European Community. Public Choice, 80(1-2), 157-172.

Duguleana, L., \& Duguleana, C. (2016). Structural Aspects of the European Union Economy. European Research Studies Journal, 2016(1), 93-128.

Edin, P. A., \& Ohlsson, H. (1991). Political determinants of budget deficits: Coalition effects versus minority effects. European Economic Review, 35(8), 1597-1603.

Fatás, A., \& Mihov, I. (2003). The case for restricting fiscal policy discretion. The Quarterly Journal of Economics, 118(4), 14191447. https://www.jstor.org/stable/25053943

Franzese Jr. R.J. (2002). Electoral and partisan cycles in economic policies and outcomes. Annual Review of Political 
Science, 5, 369-421. https://doi.org/10.1146/annurev. polisci.5.112801.080924

Fatás, A., \& Mihov, I. (2006). The macroeconomic effects of fiscal rules in the US states. Journal of Public Economics, 90(1-2), 101-117. https://doi.org/10.1016/j.jpubeco.2005.02.005

Hallerberg, M., \& Strauch, R. (2002). On the Cyclicality of fiscal policy in Europe. Empirica, 29, 183-207.

Henisz, W. J. (2004). Political institutions and policy volatility. Economics \& Politics, 16(1), 1-27. https://doi.org/10.1111/ j.1468-0343.2004.00129.x

Glazer, A. (1989). Politics and the choice of durability. American Economic Review, 79(5), 1207-1213.

Gruner, H. P. (2017). Mechanisms for the Control of Fiscal Deficits. Journal of Economic Behavior and Organization, 144, 133152. http://dx.doi.org/10.1016/j.jebo.2017.09.019

Kontopoulos, Y., \& Perotti, R. (1999). Government fragmentation and fiscal policy outcomes: Evidence from OECD countries. In: Fiscal institutions and fiscal performance (pp. 81-102). Cambridge, MA: National Bureau of Economic Research.

Lane, P. R. (2003). The cyclical behaviour of fiscal policy: evidence from the OECD. Journal of Public Economics, 87(12), 26612675. https://doi.org/10.1016/S0047-2727(02)00075-0

Lizzeri, A. (1999). Budget deficits and redistributive politics. The Review of Economic Studies, 66(4), 909-928. https://www.jstor. org/stable/2566925

Leachman, L.L., Rosas, G., Lange, P., \& Bester, A. (2007). The political economy of budget deficits. Economics and politics, 19(3), 369-420. https://doi.org/10.1111/j.14680343.2007.00320.x

Mink, M., \& De Haan, J. (2005). Has the Stability and Growth Pact Impeded Political Budget Cycles in the European Union? CESifo Working Paper 1532. Munich, Germany: CESifo Group.

Nordhaus, W. D. (1975). The political business cycle. The Review of Economic Studies, 42(2), 169-190.

Ngo, N. M., \& Nguyen, D. L. (2020). Economic Growth, Total Factor Productivity, and Institution Quality in Low-Middle Income Countries in Asia. Journal of Asian Finance, Economics and Business, 7(7), 251- 260. doi:10.13106/jafeb.2020.vol7. no7.251

Persson, T. (2001). Do political institutions shape economic policy? NBER Working Paper No. 8214. Cambridge, MA: National Bureau of Economic Research. https://www.nber.org/papers/ w8214

Persson, T., \& Svensson, L. E. (1989). Why a stubborn conservative would run a deficit: Policy with time-inconsistent preferences. The Quarterly Journal of Economics, 104(2), 325-345. DOI: $10.2307 / 2937850$

Persson, T., \& Tabellini, G. (1999). The size and scope of government: Comparative politics with rational politicians. European Economic Review, 43(4-6), 699-735. https://doi. org/10.1016/S0014-2921(98)00131-7
Person, T., \& Tabellini, G. (2001). Political institutions and policy outcomes: what are the stylized facts? CEPR Discussion Paper No. 2872. London, UK: Centre for Economic Policy Research.

Pontoh, W. (2017). The Capital Structure: Is Debt just a Policy or Requirement? European Research Studies Journal, 20(2A), 128-139.

Rogoff, K., \& Sibert, A. (1988). Elections and macroeconomic policy cycles. The Review of Economic Studies, 55(1), 1-16.

Rogoff, K. (1990). Equilibrium political budget cycles. American Economic Review, 80, 21-36.

Roubini, N., \& Sachs, J. D. (1989a). Government spending and budget deficits in the industrial countries. Economic Policy, 4(8), 99-132.

Roubini, N., \& Sachs, J. D. (1989b). Political and economic determinants of budget deficits in the industrial democracies. European Economic Review, 33(5), 903-933.

Song, Z., Storesletten, K., \& Zilibotti, F. (2012). Rotten Parents and Disciplined Children: A Politico-Economic Theory of Public Expenditure and Debt. Econometrica, 80(6), 2785-2803.

Shugart, M. S., \& Carey, J. M. (1992). Presidents and assemblies: Constitutional design and electoral dynamics. New York, NY: Cambridge University Press.

Sørensen, B. E., Wu, L., \& Yosha, O. (2001). Output fluctuations and fiscal policy: US state and local governments 1978-1994. European Economic Review, 45(7), 1271-1310.

Tabellini, G., \& Alesina, A. (1990). Voting on the budget deficit. The American Economic Review, 80(1), 37-49. https://www. jstor.org/stable/2006732

Thalassinos, I. E., Pintea, M., \& Raţiu, I. P. (2015a). The Recent Financial Crisis and Its Impact on the Performance Indicators of Selected Countries during the Crisis Period: A Reply. International Journal of Economics and Business Administration, 3(1), 3-20.

Thalassinos, I. E., Stamatopoulos, D. T., \& Thalassinos, E. P. (2015b). The European Sovereign Debt Crisis and the Role of Credit Swaps. In: W. T. Ziemba \& A.G. Malliaris (Eds.), The WSPC Handbook of Futures Markets in memory of Late Milton Miller (Nobel 1990). World Scientific Handbook in Financial Economic Series Vol. 5, Chapter 20 (pp. 605-639). doi: 10.1142/9789814566926_0020

Tran, S. H., \& Nguyen, L. T. (2020). Financial Development, Business Cycle and Bank Risk in Southeast Asian Countries. Journal of Asian Finance, Economics and Business, 7(3), 127135. doi:10.13106/jafeb.2020.vol7.no3.127

Ugurlu, E., Thalassinos, E., \& Muratoglu, Y. (2014). Modeling Volatility in the Stock Markets using GARCH Models: European Emerging Economies and Turkey. International Journal of Economics and Business Administration, 2(3), 72-87.

Wang, S., Yang, Z., \& Liu, H. (2011). Impact of urban economic openness on real estate prices: Evidence from thirty-five cities 
in China. China Economic Review, 22(1), 42-54. https://doi. org/10.1016/j.chieco.2010.08.007

Woo, J. (2003). Economic, political, and institutional determinants of public deficits. Journal of Public Economics, 87(3-4), 387-426.

Woo, J. (1999). Social Polarization, Economic Development, and Fiscal Instability: Theory and Evidence. Unpublished working paper. Cambridge, MA: Harvard University.
Wu, G. L., Feng, Q., \& Li, P. (2015). Does local governments' budget deficit push up housing prices in China? China Economic Review, 35, 183-196. https://doi.org/10.1016/j. chieco.2014.08.007

Yu, H. (2017). Impacts of the Real Effective Exchange Rate and the Government Deficit on Aggregate Output in Australia. Journal of Asian Finance, Economics and Business, 4(1), 19-23. doi: 10.13106/jafeb.2017.vol4.no1.19 